\title{
Cycling of Carbon and Other Elements in a Beech Forest Hestehave, Jutland, Denmark, in the Past 50 Years
}

\author{
Folke 0. Andersson \\ Department of Ecology, Swedish University of Agricultural Sciences, Uppsala, Sweden \\ Email: folke.andersson@slu.se
}

Received 20 February 2015; accepted 14 March 2015; published 19 March 2015

Copyright (C) 2015 by author and Scientific Research Publishing Inc.

This work is licensed under the Creative Commons Attribution International License (CC BY). http://creativecommons.org/licenses/by/4.0/

\section{(c) (i) Open Access}

\section{Abstract}

Plant biomass, primary production and mineral cycling in the beech forest (Fagus sylvatica L.), Hestehave in Jutland, Denmark were studied over a 50-year period. The role of the forest as a carbon sink was also assessed. Aboveground tree biomass was $226 \mathrm{t} \cdot \mathrm{ha}^{-1}$ in 1970 and after a 50 year $539 \mathrm{t} \cdot \mathrm{ha}^{-1}$ in 2014, an unexpected increase with $313 \mathrm{t} \cdot \mathrm{ha}^{-1}$. Annual production at those two points in time was 13.4 and $20.5 \mathrm{t} \cdot \mathrm{ha}^{-1}$, respectively. It was apparent that the tree biomass was still acting as a sink for carbon, which was the dominant element in the aboveground parts. The concentration of other elements $(\mathrm{N}>\mathrm{K}>\mathrm{Mg}>\mathrm{P}>\mathrm{S}>\mathrm{Na}>\mathrm{Mn}>\mathrm{Zn}>\mathrm{Fe}>\mathrm{Cu}$ ) ranged from 495 to $0.4 \mathrm{~kg} \cdot \mathrm{ha}^{-1}$. Annual litterfall restored $3.2 \mathrm{t} \cdot \mathrm{ha}^{-1}$ to the soil as organic matter or $1.6 \mathrm{t} \cdot \mathrm{ha}^{-1} \mathrm{as} \mathrm{carbon}$ Over the year 53\% of the litterfall was decomposed. A pH decrease of 0.95 units in the soil was observed between 1968 and 1993. This was attributed to fallout from a neighbouring thermal heating station affecting sulfur deposition and increasing soil acidification. After 1993, when filters were fitted in the heating station, the $\mathrm{pH}$ decrease in the soil was smaller, only $0.09 \mathrm{pH}-\mathrm{units}$ up to 2011. The increased tree growth is an additional, likely explanation for the observed soil acidification. Deposition of the growth-limiting element nitrogen increased during later years and is now, most likely around $20 \mathrm{~kg} \cdot \mathrm{ha}^{-1}$ per annum, which may partly contribute to the increased production.

\section{Keywords}

Plant Biomass, Primary Production, Litterfall, Deposition, Cycling of C, N, P, S and Carbon Sink

\section{Introduction}

The effects of climate change on forests may result in a major environmental issue, e.g. changes in processes 
such as forest photosynthesis, decomposition and mineralisation may affect the turnover of carbon and minerals? The question is whether the forest will become a sink for carbon mitigating climate change or a source. The carbon balance of forests is therefore an area of major concern. Data are needed to draw up budgets for carbon and other elements in the ecosystem.

This study analysed data obtained in investigations in a beech forest (Fagus sylvatica L.) in Hestehave, Jutland, Denmark, established as a part of the Danish International Biological (IBP) programme in 1967. The focus of these investigations was on primary and secondary production in forest including decomposition (See Annex 1 for major publications).

The values for tree biomass, tree productivity and mineral cycling of elements reported here have earlier only been available in an international data bank (Andersson, 1973; Thamdrup, 1973; Reichle, 1981). The mineral cycling could be addressed as other scientists made their data available to the author. Another major reason for this late publishing is that the problems actual today make the data useful and valuable as references especially in combination with the repeated measurements. New light can be shed on today's problem. Repeated measurements of tree diameter and height were therefore made in November 2014. This made it possible to discuss the changes in tree biomass and production taken place during a 50-year period.

The paper reports preliminary findings on tree biomass, production and cycling of elements and discusses possible changes in these properties in an almost 50-year perspective of these. Special emphasis is placed on carbon, nitrogen and sulfur.

\section{Research History}

Danish beech forests represent a classical subject in the research history of production ecology. In today's textbooks the classical diagram of Möller et al. (1954) can be still found indicating the different components of gross and net production over time in a beech forest. Furthermore the father of production ecology was a DaneBoysen Jensen (1932). This investigation of a Danish beech forest has therefore a strong historical background.

\section{Hestehave-A Beech Forest}

The study site, comprising 3 ha, is situated in a pure beech forest (Fagus sylvatica L.). At the time of establishment of the research programme in 1967 the forest was 85 - 95 years old with an overstory tree density of 210 trees $\cdot \mathrm{ha}^{-1}$, average tree height of $27.9 \mathrm{~m}$ and diameter at breast height $40.5 \mathrm{~cm}$ (Table 1, Figure 1). There was also an understory with 186 trees $^{-1} \mathrm{a}^{-1}$ and an average tree height of $10.6 \mathrm{~m}$. A review of part of the study site was done in November 2014 revealed some wind damage in the eastern part of the area. Some old trees, living or dead, had fallen, but the damage was restricted. Three areas (D-F/7-9, A-E/14-16 and A-B/11-12 according the original map) were identified and remeasured for tree height and diameter. They had a combined area of 0.28 ha and a tree density of 189 trees ha $^{-1}$. The most striking changes over the almost 50 years were a diameter increase of $17.5 \mathrm{~cm}$ and a tree height of $6.2 \mathrm{~m}$. Compared with the early observations, visible changes to the forest had occurred. For example, dead material had accumulated on the ground and a previously described and investtigated understory layer of beech had decreased with most of these trees having died or merged into the over story tree layer. However, the experimental area as a whole was less altered than expected and could be used for the reinvestigation.

The soil type at the site is dominated by an Ortic Luvisol. It is characterised by an underlying calcareous or agric B-horizon with clay accumulated after leaching or downwash (Dalsgaard, 1983). Another common name

Table 1. Average values of stand properties of the Danish IBP-PT beech (Fagus sylvatica) forest Hestehave, Jutland, Denmark, in spring 1970. Diameter and basal area refer to breast height $1.3 \mathrm{~m}$ above ground. Measurement I: Data supplied by G. Münter, The Royal Agriculture and Veterinary University, Copenhagen. Measurement II: Average tree diameter and height in a selected part ( 0.28 ha) of the original investigation area in November 2014.

\begin{tabular}{|c|c|c|c|c|c|c|}
\hline & Age & Density & Average height & Average diameter & Basal area & Volume \\
\hline & Years & Trees $\cdot \mathrm{ha}^{-1}$ & $\mathrm{~m}$ & $\mathrm{~cm}$ & $\mathrm{~m}^{2} \mathrm{ha}^{-1}$ & $\mathrm{~m}^{3} \mathrm{ha}^{-1}$ \\
\hline Measurement I Overstory Fagus sylvatica & $85-95$ & 210 & 27.9 & 40.5 & 27.02 & 451.6 \\
\hline Understory Fagus sylvatica & & $(186)$ & $(10.6)$ & $(9.4)$ & 1.3 & 9.8 \\
\hline Total & & 210 & 27.9 & 40.5 & 28.32 & 461.4 \\
\hline Measurement II Overstory & $129-139$ & 189 & 34.1 & 58.0 & 49.9 & 888.3 \\
\hline
\end{tabular}




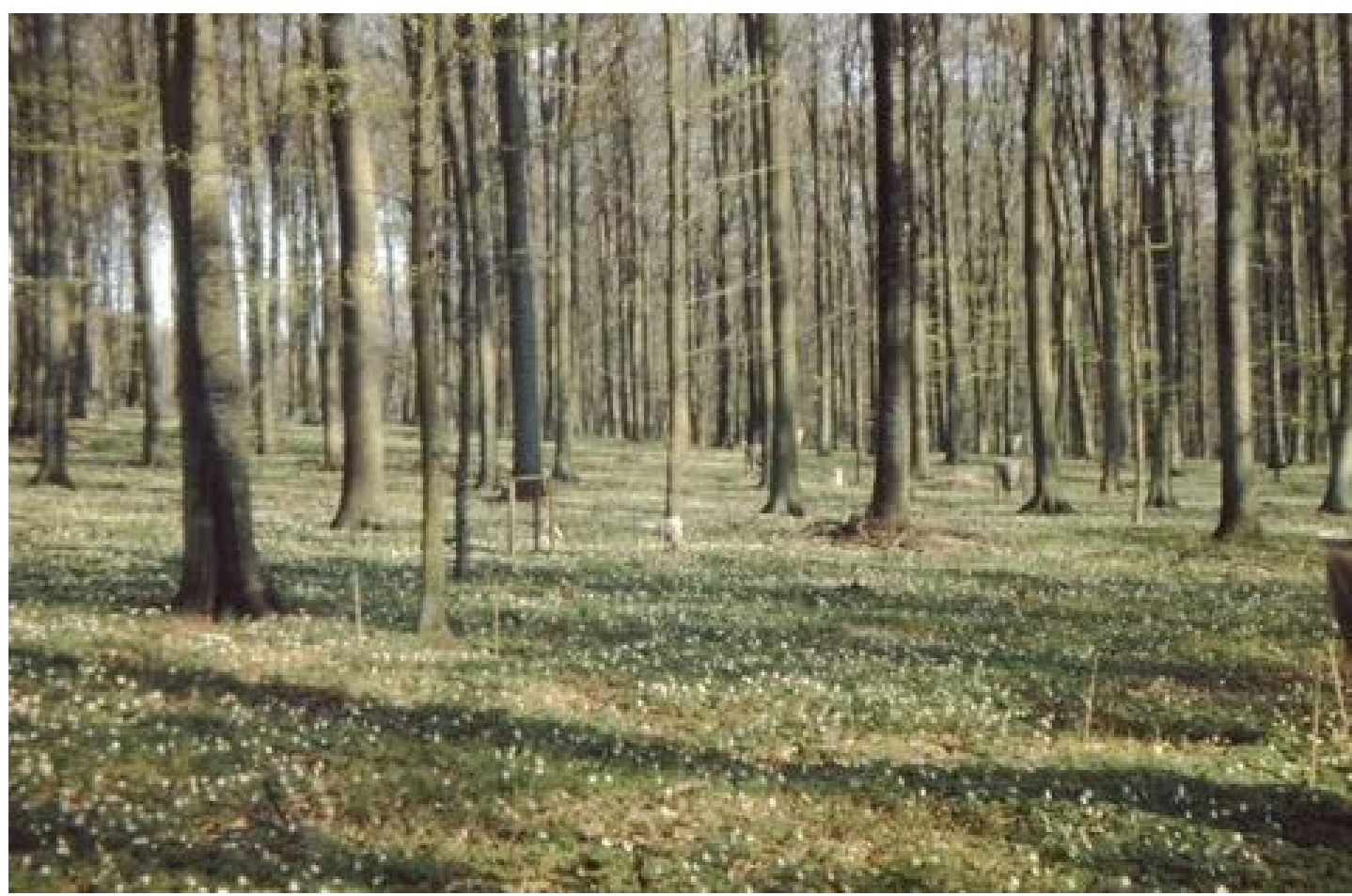

Figure 1. "In the Hall of Freja" according to Adam Oehlenschläger-the author of the National Anthem of Denmark. The Danish Beech Forest at Hestehave, Jutland Denmark in 1967. Photo: H Petersen.

could be "Parabraunerde". The pH-range for the upper $10 \mathrm{~cm}$ of the soil at the start of the project in 1967 was 4.2 - 7.6 and base saturation was $13 \%-89 \%$.

In spring a dominating species and aspect in the Hestehave forest is Anemone nemorosa, which is later followed by Asperula odorata, Carex sylvatica, Circea lutetiana, Hordeum europium, Melica uniflora and Veronica montana.

\section{Element Cycling Model}

In a previous paper, an element cycling model adapted from Nihlgård (1970, 1972) was used (Andersson, 2014). For the purposes of synthesis and comparability, the same model was used here without further adaptations.

\section{Methods}

The methods applied in this paper refer to those, which have been used by the author previously. References to earlier publications are given. Some data have been put to the author's disposal. Where essential differences exist methodologically references to additional papers are given. In short, key areas and publications are as follow:

\subsection{Biomass and Production of Trees, Shrubs and Field Layers}

The main methods used for describing trees and shrubs can be found in Andersson (1970c; 2014) and Nihlgård $(1970,1972)$. For trees and shrubs, non-destructive measurements as diameter and height were correlated in allometric regressions with destructive measurements on above- and belowground fractions. In order to make future measurements and calculations possible, the allometric regressions are given in Table 2. Eleven beech trees were sampled and measured for stem wood, bark, branches and currents twig biomass. Three sizes of stumps were excavated. Roots $>2 \mathrm{~cm}$ diameter, roots $0.5-2 \mathrm{~cm}$ and $<0.5 \mathrm{~cm}$ were also excavated in 10 pits $50 \times 50 \times$ $50 \mathrm{~cm}$. Age and tree production were estimated by yearring analysis for 5-year-periods on stem discs. For the field layer see Hughes (1975), Bülow-Olsen (1977) and Astrup \& Bülow-Olsen (1979). In the reinvestigations 2014 a tree measurement tape was used for diameter at breast height while for tree height a height meter SILVA Type 65 was used. 
Table 2. $\log _{10}$ regression data on dry weight at $\left(85^{\circ} \mathrm{C}\right)$, where $\mathrm{D}$ is tree diameter in $\mathrm{cm} 1.3 \mathrm{~m}$ above ground and $\mathrm{H}$ is tree height in $\mathrm{m}$ of the Danish IBP-PT beech forest Hestehave, Kalö, Jutland, Denmark. These regressions were used when calculating tree biomass and production for 1967.

\begin{tabular}{|c|c|c|c|c|c|c|c|c|}
\hline Regression $\log _{10} \mathrm{y}=\log _{10} X, b+\mathrm{A}$ & $\bar{x}$ & $\bar{y}$ & Intercept A & $\begin{array}{l}\text { Regr, } \\
\text { coeff B }\end{array}$ & $\begin{array}{c}\text { Corr coeff } \\
\text { R }\end{array}$ & $\begin{array}{l}\text { Mean square } \\
\text { MSG }\end{array}$ & $\begin{array}{c}\text { Total Sum } \\
\text { Square n SSQ }\end{array}$ & Sum $n$ \\
\hline $\begin{array}{l}\mathrm{D}^{2} \mathrm{H}\left(\mathrm{cm}^{2} \mathrm{~m}\right)(x) \text { on above } \\
\text { ground total biomass }(\mathrm{kg})(y)\end{array}$ & 4.1938 & 2.6174 & -1.3305 & 0.9414 & 0.999 & 0.002 & 5.204 & 11 \\
\hline $\mathrm{D}^{2} \mathrm{H}$ on stem wood + bark biomass & 4.1938 & 2.5116 & -1.4229 & 0.9382 & 0.998 & 0.002 & 5.172 & 11 \\
\hline $\mathrm{D}^{2} \mathrm{H}$ on stem wood biomass & 4.1938 & 2.4828 & -1.5357 & 0.9582 & 0.998 & 0.002 & 5.395 & 11 \\
\hline $\mathrm{D}^{2} \mathrm{H}$ on stem bark biomass & 4.1938 & 1.2612 & -1.6380 & 0.6913 & 0.984 & 0.011 & 2.894 & 11 \\
\hline $\mathrm{D}^{2} \mathrm{H}$ on branch biomass. total & 4.1938 & 1.9345 & -2.0424 & 0.9483 & 0.985 & 0.019 & 5.434 & 11 \\
\hline $\mathrm{D}^{2} \mathrm{H}$ on current twigs & 4.1938 & 0.8855 & -1.7807 & 0.6357 & 0.977 & 0.012 & 2.479 & 11 \\
\hline $\mathrm{D}^{2} \mathrm{H}$ on root biomass & 3.9285 & 1.7924 & -1.4229 & 0.9382 & 0.966 & 0.010 & 1.312 & 3 \\
\hline $\mathrm{D}^{2} \mathrm{H}$ on above ground total production & 4.1938 & 1.4690 & -1.8522 & 0.7919 & 0.988 & 0.010 & 3.762 & 11 \\
\hline $\mathrm{D}^{2} \mathrm{H}$ on stem wood and bark production & 4.1938 & 0.9588 & -2.6410 & 0.8584 & 0.991 & 0.009 & 4.396 & 11 \\
\hline $\mathrm{D}^{2} \mathrm{H}$ on stem bark production & 4.1938 & 0.7936 & -2.5467 & 0.5880 & 0.929 & 0.032 & 2.113 & 11 \\
\hline
\end{tabular}

Note: When calculating tree biomass and production for $2014 \mathrm{D}$ (Diameter) was used instead of $\mathrm{D}^{2} \mathrm{H}$ as a possible measurement error could affect the final result of the height measurements. A possible error was reduced.

\subsection{Elements and Their Distribution in Biomass and Production of the Shrub and Field Layers}

The main methods used for determining element concentrations and then their distribution in plant material are described in Andersson (1970a, 1970b; 2014) and for trees and shrubs and in Bülow-Olsen (1977) for the field layer. For chemical values in plant material for 2014 data from 1970 was used assuming the same composition today and applying an adjustment for the weight increase.

\subsection{Elements of Litterfall and Surface Litter}

The litterfall of leaves, bud scales, flowers, twigs and miscellaneous items and the degradation of leaves as well as consumption of leaves were determined in 48 litter traps with a diameter of $60 \mathrm{~cm}$ placed at random and collected monthly (Nielsen, 1977). Larger twigs, branches surface litter amounts were measured in six $10 \times 10 \mathrm{~m}$ squares. Chemical analyses were carried out according to Bülow-Olsen (1977).

\subsection{Elements in Incoming Precipitation, Throughfall and Interception}

The incoming precipitation was measured in two rain gauges outside the forest. The throughfall was measured in 24 rain gauges with an opening diameter $19.0 \mathrm{~cm}$ placed randomly within the observation plot. Stem flow was also measured on five representative trees. Chemical analyses of water samples followed Bülow-Olsen (1977). Important information on deposition rate of sulfur and nitrogen was lacking and were therefore derived from Jensen (1962), Jörgensen (1978) and Pedersen et al. (2001). Comparisons with south Swedish conditions were made.

\subsection{Soil Organic Matter Exchangeable Mineral Content and Total Mineral Content of Trees}

Soil sampling and chemical analyses followed Bülow-Olsen (1977). Analyses of tree material follow Andersson (1970c; 2014).

\subsection{Statistics}

Results are generally presented as means. Percentage errors of the mean is given at $95 \%$ confidence limits. Andersson (1970b) discusses different statistical aspects of errors in sampling and computations.

\subsection{Principles for Investigations of Changes in Tree Biomass and Productivity over Time}

A reinvestigation of a forest stand for tree biomass and production would require that the very same stand or 
sample plots and trees are revised again. In this reinvestigation three small sample areas of the original experimental area were measured representing 0.28 ha, compared to three areas of 1 ha in the original study from 1967. A map of the experimental area was available and old tree numbers and location could be identified. Unfortunately, the original data of tree diameter and height were not available. Therefore the criteria for a revision was not completely fulfilled. However, the original allometric regressions for tree biomass and production were used for new calculations using the diameter and height data from 2014. A reservation for the shortcomings at the interpretation is however expressed as error could have been introduced at the comparison.

\section{Results}

\subsection{Biomass and Production of the Tree, Shrub and Field Layers}

\subsubsection{Initial Results 1970}

The organic matter in terms of biomass and production by the tree, understory, shrub and field layers are essential carriers of mineral elements, in particular carbon. The aboveground biomass of the beech overstory in 1970 was estimated to be $220.3 \mathrm{t}^{-h^{-1}}$ (Table 3). There was also an understory, often with small trees of beech, corresponding to $5.8 \mathrm{t}^{-h \mathrm{~h}^{-1}}$. As regards the belowground system the stumps and associated roots of the overstory had an estimated tree biomass of $38.9 \mathrm{t}^{-h^{-1}}$. An additional $3.8 \mathrm{t} \cdot \mathrm{ha}^{-1}$ of stumps and roots was estimated for the understory giving a total of $42.7 \mathrm{t} \cdot \mathrm{ha}^{-1}$ for the belowground system of beech trees. This gave a total of 268.2 $t \cdot h a^{-1}$ of tree biomass for the beech forest.

In terms of annual biomass productivity a rate of $13.65 \mathrm{t} \cdot \mathrm{ha}^{-1}$ was found for the aboveground parts of the overstory. Examination of the distribution into different fractions revealed that the understory of beech yielded an additional $1.13 \mathrm{t} \cdot \mathrm{ha}^{-1}$ annually. The production of the belowground parts was at a low estimate of $2.37 \mathrm{t} \cdot \mathrm{ha}^{-1}$. However, this is known to be an underestimate and needs to be interpreted as such, as the methodology used only considered larger roots and the rapid turnover of finer roots or hairs are were overlooked. The total productivity of the beech forest was $17.15 \mathrm{t} \cdot \mathrm{ha}^{-1}$.

The total plant biomass and the annual production rate of the field layer was marginal relative to those of the tree layer (Table 4). The productivity was estimated to $1066 \mathrm{~kg} \cdot \mathrm{ha}^{-1}$, with $55 \%$ and $45 \%$ aboveground and belowground, respectively.

The tree biomass was also determined as carbon (Table 5). A total of $103.7 \mathrm{t} \cdot \mathrm{ha}^{-1}$ was found for the aboveground parts including both overstory and understory. An additional $18.8 \mathrm{t}^{-\mathrm{ha}^{-1}}$ was provided by the belowground parts giving a total of $122.5 \mathrm{t} \cdot \mathrm{ha}^{-1}$. The field layer was also considered.

\subsubsection{Results 50 Years Later}

Based on results from other investigations in a mature mixed oak wood in southern Sweden (Andersson, 2014) it was concluded that Hestehave beech forest was most likely still in an aggrading phase accumulating biomass in trees. This indicates that the forest ecosystem was acting as a sink for carbon. This fact became a hypothesis worthwhile testing on other forests. The ongoing publishing of the Hestehave work was then in November 2014 combined with a revision of tree diameter and height in 2014 in order to test the hypothesis.

The most striking feature of the beech forest when revisited after almost 50 years was the increased tree diameter and height, changes which were visible for the naked eye (See Table 1, Figure 2). The tree biomass had increased from 220 to $539 \mathrm{t}^{\mathrm{t}} \mathrm{ha}^{-1}$ or by $154 \%$ and the tree production from 13.4 to $20.5 \mathrm{t} \cdot \mathrm{ha}^{-1}$ or $53 \%$ (Table 6). Due to high costs and the uncertainties, only the aboveground parts were considered. In terms of carbon there had been an increase from 101 to $245 \mathrm{t}^{\circ} \mathrm{ha}^{-1}$ or $142 \%$.

Thus it was confirmed that the beech forest still is acting as a carbon sink when considering the aboveground parts alone.

\subsection{Elements and Distribution in Tree Biomass, Production and Field Layer}

In the aboveground parts calcium (Ca) and nitrogen (N) were the dominating elements with 867 and $495 \mathrm{~kg} \cdot \mathrm{ha}^{-1}$, respectively, followed by potassium $(\mathrm{K})>$ magnesium $(\mathrm{Mg})>$ phosphorous $(\mathrm{P})>\operatorname{sulphur}(\mathrm{S})>\operatorname{sodium}(\mathrm{Na})>$ manganese $(\mathrm{Mg})>$ zinc $(\mathrm{Zn})>$ iron $(\mathrm{Fe})$ and cupper $(\mathrm{Cu})$ ranging from $292-0.4 \mathrm{~kg} \cdot \mathrm{ha}^{-1}$ (Table 5). In the belowground parts the order was $\mathrm{N}$ and $\mathrm{N}$ followed by the elements $\mathrm{K}>\mathrm{Mg}>\mathrm{P}>\mathrm{Na}$ ranging from $113-18$ $\mathrm{kg} \cdot \mathrm{ha}^{-1}$ and minor amounts of the other elements analysed. 
Table 3. Plant biomass and yearly production of the tree layer in the Danish IBP-PT beech forest Hestehave, Kalö, Jutland, Denmark. Figures given as metric $t \cdot \mathrm{ha}^{-1}$ dry weight $\left(85^{\circ} \mathrm{C}\right)$. Standard error at $95 \%$ confidence limits. Production figures for 1967 represent the mean for the five year period 1966-1970. Biomass figures correspond to the growing period 1967.

\begin{tabular}{|c|c|c|}
\hline & 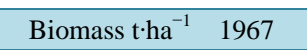 & Net productivity tha ${ }^{-1} 1967$ \\
\hline \multicolumn{3}{|l|}{ Overstory } \\
\hline \multicolumn{3}{|l|}{ Above ground } \\
\hline Stem wood & $163.0 \pm 1.3$ & $4.50 \pm 0.070$ \\
\hline Stem bark & $7.4 \pm 0.1$ & $0.22 \pm 0.006$ \\
\hline Branches (total) & $46.9 \pm 1.1$ & $5.70 \pm 0.200$ \\
\hline Current twigs & $3.0 \pm 0.1$ & $3.00 \pm 0.050$ \\
\hline Blades & & $2.23(74.4 \%)$ \\
\hline Buds & & $0.34(11.4 \%)$ \\
\hline Twigs & & 0.27 (8.9\%) \\
\hline Petioles & & $0.16(5.3 \%)$ \\
\hline Additional production-litter fall & & $0.23 \pm 0.026$ \\
\hline Total above ground biomass & $220.3 \pm 2.5538 .9(1.1 \%)$ & $13.65 \pm 0.352(2.6 \%)$ \\
\hline \multicolumn{3}{|l|}{ Below ground } \\
\hline \multicolumn{3}{|l|}{ Stump and tree roots } \\
\hline Stump and roots $>2 \mathrm{~cm}$ & 12.2 & \\
\hline Roots $0.5-2.0 \mathrm{~cm}$ & 14.0 & \\
\hline Roots $<0.5 \mathrm{~cm}$ & 9.2 & \\
\hline Additional roots $>0.5 \mathrm{~cm}$ & $2.9 \pm 0.8$ & \\
\hline Total below ground biomass & $38.3 \pm 1.9(5 \%)$ & 2.28 (арp.) \\
\hline Total above and below ground & $258.6 \pm 3.4(1.3 \%)$ & 15.93 \\
\hline \multicolumn{3}{|l|}{ Understory } \\
\hline \multicolumn{3}{|l|}{ Above ground } \\
\hline Stem and branches & 5.4 (арр.) & 0.75 (арp.) \\
\hline Current twigs & 0.4 (арp.) & 0.38 (app.) \\
\hline Total above ground & 5.8 & 1.13 \\
\hline Below ground & 3.8 (app.) & 0.09 (app.) \\
\hline \multicolumn{3}{|l|}{ Stump and roots } \\
\hline Total above and below ground & 9.6 & 1.22 \\
\hline Total Overstory and Understory Biomass & 268.2 & 17.15 \\
\hline \multicolumn{3}{|l|}{ Overstory and Understory Volumes } \\
\hline \multicolumn{3}{|l|}{ In $^{3} \cdot \mathrm{ha}^{-1}$} \\
\hline Volume of stems and branches on bark & 425.7 & \\
\hline Production volume & 14.7 & \\
\hline
\end{tabular}

\subsection{Elements of Litterfall and Surface Litter}

In functional analyses the forest litterfall and surface litter are essential components (Table 7). The litterfall in $1970 \mathrm{had}$ an organic matter content of $3230 \mathrm{~kg} \cdot \mathrm{ha}^{-1}$ corresponding to $1620 \mathrm{carbon} \mathrm{kg} \cdot \mathrm{ha}^{-1}$. This amount was returned to the soil in that yearly. However, there was a great variation between years as in 1971 the corresponding amount was estimated to be $4030 \mathrm{~kg} \cdot \mathrm{ha}^{-1}$. The other elements were returned to the litter layer in the following order $\mathrm{N}>\mathrm{Ca}>\mathrm{K}>\mathrm{Mg}>\mathrm{Na}>\mathrm{P}$ ranging from $34-1.7 \mathrm{~kg} \cdot \mathrm{ha}^{-1}$. The surface litter consisted of branches and smaller fraction comprising $7490 \mathrm{~kg} \cdot \mathrm{ha}^{-1}$ from which more Ca was returned more than N (Table 7).

\subsection{Elements in Incoming Precipitation, Stem Flow, Throughfall and Interception}

Input of elements by rain to forest is important. Here it was measured in an open field (In). Some of the rain and its elements fall through the tree canopy as throughfall (T) and some follows the trunk of the trees as stem flow (ST). There is a difference between what comes in and what reaches the soil (Diff) and this difference can be negative or positive. For the precipitation a negative difference means that water has been lost by interception. For elements a negative value is a result of uptake, while a positive value means a leaching of elements from the canopy. 
Table 4. Yearly productivity of the field layer in $\mathrm{kg} \cdot \mathrm{ha}^{-1}$ at dry weight $\left(65^{\circ} \mathrm{C}\right)$ in the Danish IBP-PT beech forest in Hestehave, Kalö, Jutland, Denmark. Data for 1970. Figures supplied by A. Bülow-Olsen. A = Aboveground; B = Belowground.

\begin{tabular}{|c|c|c|c|c|c|c|c|c|c|c|}
\hline Period & & $1.4-8.6$ & $9.6-21.6$ & $22.6-9.7$ & $10.7-3.8$ & $4.8-2.9$ & 3.9- 12.10 & 13.10 - 15.12 & Total & Per year \\
\hline Days & & 68 & 13 & 18 & 25 & 30 & 40 & 53 & 247 & \\
\hline \multirow{2}{*}{ Anemone nemorosa } & A & 159 & - & - & - & - & - & - & 159 & \\
\hline & B & - & - & 34 & - & - & & - & 34 & 193 \\
\hline \multirow{2}{*}{ Ranunculus ficaria } & A & 23 & - & - & - & - & - & - & 23 & \\
\hline & B & $?$ & ? & - & - & - & - & - & $?$ & 23 \\
\hline \multirow{2}{*}{ Oxalis acetosella } & A & 17 & - & 33 & - & 2 & - & - & 52 & \\
\hline & B & 7 & - & 27 & - & - & 18 & - & 52 & 104 \\
\hline \multirow{2}{*}{ Melica uniflora } & A & 50 & 33 & 44 & - & - & 24 & - & 151 & \\
\hline & B & 28 & - & 7 & - & - & 59 & - & 154 & 305 \\
\hline \multirow{2}{*}{ Hordeum europeum } & A & 1 & 6 & - & - & 16 & 3 & 1 & 27 & \\
\hline & B & 5 & 10 & - & 7 & - & 6 & - & 28 & 55 \\
\hline \multirow{2}{*}{ Carex sylvatica } & A & 10 & - & 40 & 91 & 32 & - & 3 & 176 & \\
\hline & B & - & 3 & 27 & 59 & 43 & - & 18 & 150 & 326 \\
\hline Sum of & A & 260 & 39 & 117 & 91 & 50 & 27 & 4 & 588 & \\
\hline Sum of & B & 40 & 13 & 155 & 66 & 43 & 83 & 18 & 418 & \\
\hline Sum of $A$ and $B$ & & 300 & 52 & 272 & 157 & 93 & 110 & 22 & 1066 & \\
\hline
\end{tabular}

Table 5. Weights of biomass and mineral contents in the tree and field layers of the Danish IBP-PT beech forest Hestehave. Kalö. Jutland. Denmark. Material sampled October 1970.

\begin{tabular}{|c|c|c|c|c|c|c|c|c|c|c|c|c|c|c|}
\hline & Biomass & $\mathrm{C}$ & $\mathrm{N}$ & $\mathrm{C} / \mathrm{N}$ & $\mathrm{Na}$ & $\mathrm{K}$ & $\mathrm{Ca}$ & $\mathrm{Mg}$ & $\mathrm{Fe}$ & $\mathrm{Mn}$ & $\mathrm{Zn}$ & $\mathrm{Cu}$ & $\mathrm{P}$ & S \\
\hline & \multicolumn{3}{|c|}{$\mathrm{t} \cdot \mathrm{ha}^{-1}$} & \multicolumn{5}{|l|}{ ratio } & \multicolumn{2}{|c|}{$\mathrm{kg} \cdot \mathrm{ha}^{-1}$} & & & & \\
\hline \multicolumn{15}{|l|}{ Above Ground } \\
\hline \multicolumn{15}{|l|}{ Overstory } \\
\hline Stem wood & 163.0 & 77.3 & 0.163 & 474 & 7.3 & 164 & 232 & 51 & 1.88 & 3.5 & 2.45 & 0.171 & 12.9 & 17.8 \\
\hline Stem bark & 7.4 & 3.1 & 0.054 & 56 & 2.0 & 15 & 210 & 4 & 0.70 & 1.0 & 0.25 & 0.036 & 3.8 & 4.1 \\
\hline Branches (total) & 46.9 & 19.2 & 0.207 & 93 & 10.0 & 87 & 363 & 27 & 1.98 & 3.8 & 2.15 & 0.210 & 28.1 & 15.5 \\
\hline Current twigs & 3.0 & 1.36 & 0.051 & --- & 2.5 & 16 & 39 & 6 & 0.24 & 0.5 & 0.04 & 0.017 & 7.2 & 3.3 \\
\hline Blades & 2.23 & 1.03 & 0.041 & 25 & 2.2 & 13 & 26 & 5 & 0.20 & 0.3 & 0.01 & 0.009 & 4.6 & 2.8 \\
\hline Buds & 0.34 & 0.15 & 0.005 & 31 & 0.1 & 1 & 5 & 0.4 & 0.01 & 0.1 & 0.01 & 0.004 & 1.2 & 0.2 \\
\hline Twigs & 0.27 & 0.11 & 0.003 & 43 & 0.1 & 1 & 6 & 0.3 & 0.01 & 0.1 & 0.01 & 0.003 & 0.8 & 0.2 \\
\hline Petioles & 0.16 & 0.07 & 0.002 & 34 & 0.1 & 1 & 2 & 0.3 & 0.02 & 0.0 & 0.01 & 0.001 & 0.4 & 0.1 \\
\hline Understory total & 5.8 & 2.61 & 0.017 & 153 & 0.9 & 9 & 21 & 2.8 & 0.15 & 0.3 & 0.14 & 0.013 & 2.0 & 1.7 \\
\hline Field layer & 0.18 & 0.08 & 0.032 & 20 & 0.2 & 1 & 2 & 0.6 & 0.02 & 0.6 & 0.08 & 0.001 & 0.4 & 0.2 \\
\hline Total Aboveground & 226.3 & 103.7 & 0.495 & - & 22.9 & 292 & 867 & 91.4 & 5.0 & 9.7 & 5.11 & 0.418 & 54.6 & 43.7 \\
\hline \multicolumn{15}{|l|}{ Below Ground } \\
\hline \multicolumn{15}{|l|}{ Overstory } \\
\hline \multicolumn{15}{|l|}{ Stump and tree roots } \\
\hline Stump and roots $>2 \mathrm{~cm}$ & 12.2 & 5.5 & 0.079 & 70 & 3.5 & 22 & 43 & 7.2 & 5.2 & 0.6 & 0.41 & 0.054 & 6.8 & 1.6 \\
\hline Roots $0.5-2.0 \mathrm{~cm}$ & 14.0 & 6.2 & 0.075 & 82 & 5.7 & 29 & 85 & 11.6 & 18.3 & 1.5 & 0.71 & 0.124 & 11.1 & 2.4 \\
\hline Roots $>0.5 \mathrm{~cm}$ & 12.1 & 5.3 & 0.101 & 53 & 7.4 & 53 & 83 & 18.5 & 41.0 & 2.8 & 1.12 & 0.146 & 11.4 & 3.9 \\
\hline Understory. total & 3.8 & 1.7 & 0.020 & 134 & 1.6 & 8 & 23 & 3.2 & 5.0 & 0.4 & 0.35 & 0.146 & 3.6 & 1.2 \\
\hline Field layer & 0.22 & 0.1 & 0.004 & 25 & 0.1 & 1 & 2 & 0.5 & 1.3 & 0.7 & 0.02 & 0.003 & 0.3 & 0.1 \\
\hline Total Belowground & 42.3 & 18.8 & 0.279 & - & 18.3 & 113 & 236 & 41.0 & 70.8 & 6.0 & 2.61 & 0.473 & 33.2 & 9.2 \\
\hline Sum of Above- and Belowground & 268.6 & 122.5 & 0.774 & - & 41.2 & 405 & 1103 & 132.4 & 75.8 & 15.7 & 7.90 & 0.881 & 87.8 & 52.9 \\
\hline
\end{tabular}

Deposition of elements in forest occurs in two forms, wet and dry, where the later refers to aerosols in some deposited in one way or the other. The yearly deposition in the Hestehave beech forest was followed for one year. Data for $\mathrm{Na}, \mathrm{K}, \mathrm{Ca}, \mathrm{Mg}, \mathrm{Mn}$ and $\mathrm{P}$ are given in Table 8. Two important elements were missing, S and N. In the period between 1970 and 2014 major changes in air pollution have taken place in the Nordic countries, especially for $\mathrm{S}$ and $\mathrm{N}$ components. Although data on these changes of these elements were lacking for Hestehave 


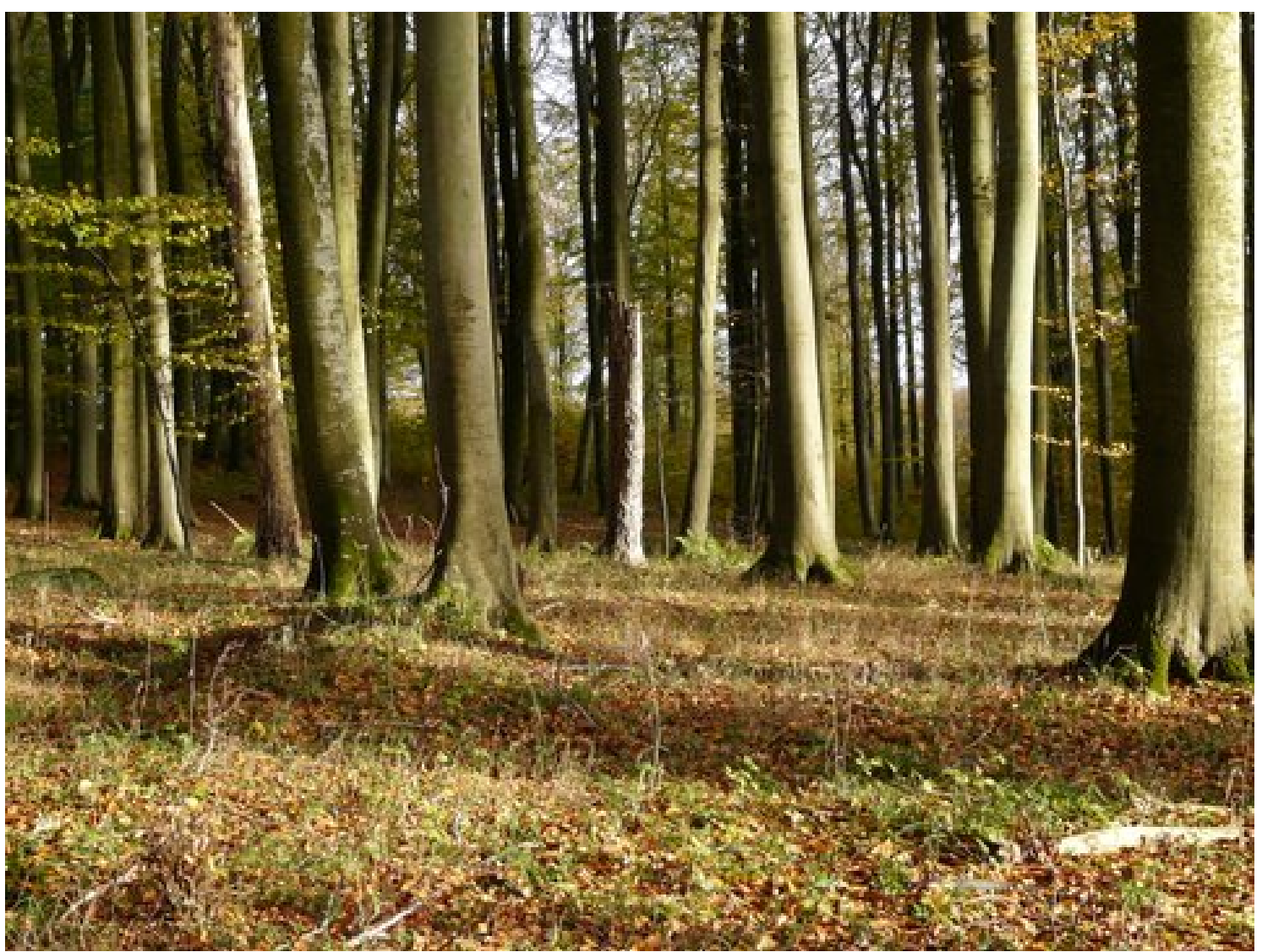

Figure 2. " In the Hall of Freja” according to Adam Oehlenschläger-the author of the National Anthem of Denmark. The Danish Beech Forest at Hestehave, Jutland, Denmark 47 years later in 2014. Photo: H Petersen.

Table 6. Tree biomass and production and carbon and nitrogen dynamics over a 44-year perspective in a European beech forest (Hestehave. Jutland, Denmark). Data for 1970 compared with data from 2014 based on a remeasured tree diameter applied in previous allometric regressions. Element content in 2014 was assumed to be the same as in 1970.

\begin{tabular}{|c|c|c|c|c|c|c|c|c|c|c|}
\hline \multirow{3}{*}{ Fraction } & \multirow{2}{*}{\multicolumn{2}{|c|}{$\begin{array}{c}\text { Tree biomass } \\
\qquad \mathrm{t} \cdot \mathrm{ha}^{-1}\end{array}$}} & \multirow{2}{*}{\multicolumn{2}{|c|}{$\begin{array}{c}\text { Tree production } \\
\mathrm{t} \cdot \mathrm{ha}^{-1}\end{array}$}} & \multirow{2}{*}{\multicolumn{2}{|c|}{$\begin{array}{l}\text { Carbon } \\
\text { t.ha }\end{array}$}} & \multirow{2}{*}{\multicolumn{2}{|c|}{$\begin{array}{c}\text { Nitrogen } \\
\mathrm{kg} \cdot \mathrm{ha}^{-1}\end{array}$}} & \multirow{2}{*}{\multicolumn{2}{|c|}{$\begin{array}{l}\text { Sulfur } \\
\mathrm{kg} \cdot \mathrm{ha}^{-1}\end{array}$}} \\
\hline & & & & & & & & & & \\
\hline & 1970 & 2014 & 1970 & 2014 & 1970 & 2014 & 1970 & 2014 & 1970 & 2014 \\
\hline Stem wood & 163.0 & 388.2 & 4.50 & 11.0 & 77.3 & 184.0 & 163 & 388 & 17.8 & 42.9 \\
\hline Stem bark & 7.4 & 13.6 & 0.22 & 0.5 & 3.1 & 5.7 & 54 & 99 & 4.1 & 7.5 \\
\hline Branches & 46.9 & 133.2 & 5.70 & 5.1 & 19.2 & 54.2 & 207 & 588 & 15.5 & 44.0 \\
\hline Current twigs & 3.0 & 3.9 & 3.00 & 3.9 & 1.4 & 1.4 & 51 & 66 & 3.8 & 4.9 \\
\hline Sum & 220.3 & 538.9 & 13.42 & 20.5 & 101.0 & 245.3 & 475 & 1141 & 41.2 & 98.8 \\
\hline
\end{tabular}

forest it was deemed important to describe these changes as they are important for a long-term maintenance of biomass production. Some old and new information from the area was therefore synthesized (Table 9).

The nearest measurement station to Hestehave is Ödum. There $12 \mathrm{~kg} \cdot \mathrm{ha}^{-1} \mathrm{~S}$ and $7 \mathrm{~kg} \cdot \mathrm{ha}^{-1} \mathrm{~N}$ was measured yearly around 1960 in an open field (Jensen, 1962). For the open field in 1970 the amount of S could be estimated to be higher and $\mathrm{N}$ only slightly higher. The throughfall in the Hestehave forest then could have had an $\mathrm{S}$ content of 15 - $25 \mathrm{~kg} \cdot \mathrm{ha}^{-1}$ yearly. We assume that the tree growth was limited by nitrogen and therefore the throughfall contained less $\mathrm{N}$ than the incident rain as an uptake in the canopy took place. This is supported by data from southernmost Sweden and general knowledge. Information from Skovbjerg indicates realistic values of today. Values from Sepstrup Sande/Tange give the present situation of deposition for Hestehave with still less $\mathrm{S}$ and more $\mathrm{N}$. 
Table 7. Content of different elements in litterfall 1970 (L) and surface litter (SL) in the Danish IBP-PT beech forest in Hestehave, Kalö, Jutland, Denmark. Figures supplied by B. Overgaard Nielsen and chemical data on litterfall by M. Astrup.

\begin{tabular}{|c|c|c|c|c|c|c|c|c|c|c|c|c|c|}
\hline \multirow{2}{*}{ Period } & Org. matter & $\mathrm{C}^{\mathrm{a}}$ & $\mathrm{N}$ & $\mathrm{Na}$ & $\mathrm{K}$ & $\mathrm{Ca}$ & $\mathrm{Mg}$ & $\mathrm{Mn}$ & $\mathrm{Fe}$ & $\mathrm{Zn}$ & $\mathrm{Cu}$ & $\mathrm{P}$ & $\mathrm{S}$ \\
\hline & \multicolumn{13}{|c|}{$\mathrm{kg} \cdot \mathrm{ha}^{-1}$} \\
\hline Dec 1969-April 1970 & 127 & 63 & - & - & - & - & - & 0.05 & - & - & - & - & - \\
\hline May 1970 & 271 & 136 & 2.4 & 0.04 & 0.25 & 1.40 & 0.16 & 0.05 & - & - & - & 0.08 & - \\
\hline June 1970 & 107 & 53 & 2.1 & 0.05 & 0.59 & 0.55 & 0.13 & 0.02 & - & - & - & 0.15 & - \\
\hline July 1970 & 64 & 32 & 0.6 & 0.02 & 0.04 & 0.34 & 0.03 & 0.01 & - & - & - & 0.02 & - \\
\hline Aug 1970 & 89 & 46 & 1.5 & 0.04 & 0.32 & 0.73 & 0.11 & 0.02 & - & - & - & 0.07 & - \\
\hline Sept 1970 & 233 & 116 & 3.1 & 0.18 & 0.93 & 2.14 & 0.37 & 0.10 & - & - & - & 0.16 & - \\
\hline Oct 1970 & 1802 & 901 & 18.3 & 1.60 & 5.27 & 20.54 & 3.38 & 1.09 & - & - & - & 0.94 & - \\
\hline Nov 1970 & 541 & 271 & 5.6 & 0.46 & 1.10 & 6.70 & 0.95 & 0.30 & - & - & - & 0.29 & - \\
\hline Litterfall (L) & 3234 & 1618 & 33.6 & 2.39 & 8.50 & 32.40 & 5.13 & 1.64 & - & - & - & 1.71 & - \\
\hline \multicolumn{14}{|l|}{ Surface litter (SL): } \\
\hline Small fraction & $4270 \pm 870$ & 1420 & 48.3 & 1.26 & 9.99 & 50.1 & 8.16 & 2.40 & 23.9 & 0.34 & 0.11 & 4.78 & 1.92 \\
\hline Large branches & $3220 \pm 440$ & 1232 & 20.7 & 0.74 & 3.77 & 32.7 & 2.30 & 0.55 & 1.5 & 0.15 & 0.06 & 1.92 & 0.68 \\
\hline Surface Litter (SL) & 7490 & 2652 & 69.0 & 2.00 & 13.76 & 82.8 & 10.46 & 2.95 & 25.4 & 0.49 & 0.17 & 6.70 & 2.60 \\
\hline Total Litter (L + SL) & 10,724 & 4270 & 102.6 & 4.39 & 22.26 & 115.2 & 15.59 & 4.59 & - & - & - & 8.41 & - \\
\hline
\end{tabular}

a = approx. values (50\% C g ${ }^{-1}$ dry matter).

A decrease in soil $\mathrm{pH}$ (measured in water solution) was found for Hestehave between 1968 and 1993 of 0.95 units (Dalsgaard K in Pedersen, 2011). After 1993 the decrease was smaller, only 0.09 pH-units up to 2011. It was concluded that there was a thermal heat plant in the vicinity of Hestehave and deposition of acidifying substances impacted the Hestehave forest. After 1993 the impact was smaller as filters were introduced at the plant.

\subsection{Soil Organic Matter and Exchangeable Mineral Content}

The organic matter content of the soil (SOM) down to $80 \mathrm{~cm}$ depth was estimated to be $141 \mathrm{t} \cdot \mathrm{ha}^{-1}$ or $71 \mathrm{t} \cdot \mathrm{ha}^{-1}$ as carbon and the nitrogen content was $7.5 \mathrm{t}^{-\mathrm{ha}^{-1}}$ (Table 10). The exchangeable (Exch) amounts in an extraction with ammonium acetate (Am-Ac) were in the order decreasing order: $\mathrm{Mn}>\mathrm{Ca}>\mathrm{Fe}>\mathrm{N}>\mathrm{K}$. It would be possible to estimate soil respiration, using the annual temperature of the soil to predict the rate of soil respiration (Bahn et al., 2010).

The dynamics of the elements in the system is seen in Table 11. The elements have different turnover times. Sodium and nitrogen are turned over more rapidly than potassium, calcium, manganese and phosphorous.

\section{Discussion}

This paper focuses on total plant biomass, annual tree production and mineral cycling in the Hestehave beech forest in Jutland, Denmark. Special attention was paid to beech tree biomass and production as almost half a century of changes could be assessed. Between 1970 and 2014, total aboveground tree biomass increased from $226 \mathrm{t} \cdot \mathrm{ha}^{-1}$ to $539 \mathrm{t} \cdot \mathrm{ha}^{-1}$ or by $313 \mathrm{t} \cdot \mathrm{ha}^{-1}$. In terms of tree productivity, annual biomass production rate, increased from 13.4 to $20.5 \mathrm{t} \cdot \mathrm{ha}^{-1}$ in the same period. The yearly loss of biomass as litterfall was estimated to be around 6 $t \cdot h a^{-1}$. The increase in tree diameter and height observed in 2014 was in line with this increase.

For other beech forests representing different fertility levels the total aboveground biomass has been reported to range from 225 to $315 \mathrm{t}^{\mathrm{th}} \mathrm{h}^{-1}$ and the net annual production from 10.6 to $17.7 \mathrm{t} \cdot \mathrm{ha}^{-1}$ (Nihlgård \& Lindgren, 1977; Ellenberg et al., 1986). The values for the Hestehave forest in 1970 fall within this range. However, the tree biomass and productivity in 2014 were unexpectedly high. During the last 50 years the beech forest has been in an aggrading phase accumulating carbon in the aboveground parts at a yearly rate of $6.0 \mathrm{tha}^{-1}$ carbon. Around $57 \%$ of the litterfall was decomposed during a year. The available data did not allow any interpretations regarding the belowground system in the forest as a sink/source function.

The observed soil acidification could be explained by the deposition of sulfur compounds. A contributing factor could also be the extreme tree production during the last 50 years, which also implies that cations are taken up by the trees, which leads to an acidification (Ågren \& Andersson, 2012; Tamm \& Hallbäcken, 1988). 
Table 8. Precipitation and concentrations of elements in precipitation (In), throughfall (T), stem flow (SF) and interception (Diff.) for the period May 1970-April 1971 in the Danish IBP-PT beech forest in Hestehave, Kalö, Jutland, Denmark. Values supplied by M. Astrup.

\begin{tabular}{|c|c|c|c|c|c|c|c|c|}
\hline \multirow{2}{*}{ Period } & \multirow{2}{*}{$\begin{array}{l}\text { Precipitation } \\
\text { type }\end{array}$} & \multirow{2}{*}{$\begin{array}{c}\text { Quantity } \\
\text { mm }\end{array}$} & $\mathrm{Na}$ & $\mathrm{K}$ & $\mathrm{Ca}$ & $\mathrm{Mg}$ & $\mathrm{Mn}$ & $\mathrm{P}$ \\
\hline & & & \multicolumn{6}{|c|}{$\mathrm{kg} \cdot \mathrm{ha}^{-1}$} \\
\hline \multirow{5}{*}{ May 1970} & In & 41.1 & 1.03 & 1.47 & 0.86 & 0.25 & 0.02 & 0.10 \\
\hline & $\mathrm{T}$ & 21.2 & 1.70 & 2.14 & 0.81 & 0.45 & 0.02 & 0.13 \\
\hline & $\mathrm{SF}$ & 1.7 & 0.15 & 0.16 & 0.05 & 0.02 & - & 0.01 \\
\hline & $\mathrm{T}+\mathrm{SF}$ & 22.9 & 1.85 & 2.30 & 0.86 & 0.47 & 0.02 & 0.14 \\
\hline & Diff & -18.2 & +0.82 & +0.83 & 0 & +0.22 & 0 & +0.04 \\
\hline \multirow{5}{*}{ June 1970} & In & 46.5 & 0.99 & 1.61 & 1.91 & 0.46 & 0.01 & 0.19 \\
\hline & $\mathrm{T}$ & 30.1 & 1.37 & 2.87 & 1.07 & 0.44 & 0.02 & 0.27 \\
\hline & SF & 5.2 & 0.10 & 0.43 & 0.43 & 0.04 & 0 & 0.03 \\
\hline & $\mathrm{T}+\mathrm{SF}$ & 35.3 & 1.47 & 3.30 & 1.20 & 0.48 & 0.02 & 0.30 \\
\hline & Diff & -11.2 & +0.48 & +1.69 & +0.71 & +0.02 & +0.01 & +0.11 \\
\hline \multirow{5}{*}{ July 1970} & In & 70.1 & 1.31 & 1.03 & 1.54 & 0.45 & 0.02 & 0.13 \\
\hline & $\mathrm{T}$ & 41.1 & 1.79 & 1.19 & 1.48 & 0.59 & 0.03 & 0.20 \\
\hline & SF & 6.4 & 0.19 & 0.25 & 0.22 & 0.07 & 0.01 & 0.02 \\
\hline & $\mathrm{T}+\mathrm{SF}$ & 47.5 & 1.98 & 1.44 & 1.70 & 0.66 & 0.04 & 0.22 \\
\hline & Diff & -22.6 & +0.67 & +0.41 & +0.16 & +0.21 & +0.02 & +0.09 \\
\hline \multirow{5}{*}{ Aug 1970} & In & 33.3 & 0.68 & 0.79 & 0.93 & 0.27 & 0.01 & 0.13 \\
\hline & $\mathrm{T}$ & 15.5 & 1.23 & 0.84 & 0.80 & 0.32 & 0.03 & 0.11 \\
\hline & SF & 2.8 & 0.10 & 0.21 & 0.10 & 0.03 & 0 & 0.01 \\
\hline & $\mathrm{T}+\mathrm{SF}$ & 18.3 & 1.33 & 1.05 & 0.90 & 0.35 & 0.03 & 0.12 \\
\hline & Diff & -15.0 & +0.65 & +0.26 & -0.03 & +0.08 & +0.02 & -0.01 \\
\hline \multirow{5}{*}{ Sept 1970} & In & 86.0 & 1.93 & 1.37 & 3.06 & 0.86 & 0.02 & 0.56 \\
\hline & $\mathrm{T}$ & 49.4 & 3.14 & 2.78 & 2.43 & 1.04 & 0.07 & 0.30 \\
\hline & SF & 8.1 & 0.34 & 0.68 & 0.36 & 0.15 & 0.02 & 0.08 \\
\hline & $\mathrm{T}+\mathrm{SF}$ & 57.5 & 3.48 & 3.46 & 2.79 & 1.19 & 0.09 & 0.38 \\
\hline & Diff & -28.5 & +1.55 & +2.09 & -0.27 & 0.33 & -0.07 & -0.18 \\
\hline \multirow{5}{*}{ Oct 1970} & In & 44.1 & 5.04 & 1.03 & 0.65 & 0.46 & 0.04 & 0.08 \\
\hline & $\mathrm{T}$ & 25.5 & 7.88 & 2.50 & 1.21 & 0.93 & 0.04 & 0.09 \\
\hline & SF & 4.9 & 1.28 & 1.40 & 0.29 & 0.23 & 0.03 & 0.02 \\
\hline & $\mathrm{T}+\mathrm{SF}$ & 30.4 & 9.16 & 3.90 & 1.50 & 1.16 & 0.07 & 0.11 \\
\hline & Diff & -13.7 & +4.12 & 2.87 & +0.85 & +0.70 & +0.03 & +0.03 \\
\hline \multirow{5}{*}{ Nov 1970} & In & 115.1 & 3.06 & 1.66 & 2.19 & 0.70 & 0.04 & 0.05 \\
\hline & $\mathrm{T}$ & 74.6 & 6.33 & 2.54 & 2.54 & 1.10 & 0.07 & 0.12 \\
\hline & SF & 21.2 & 5.96 & 3.80 & 3.26 & 2.47 & 0.15 & 0.08 \\
\hline & $\mathrm{T}+\mathrm{SF}$ & 95.8 & 12.29 & 6.34 & 5.80 & 3.57 & 0.22 & 0.20 \\
\hline & Diff & -19.3 & +9.23 & +4.68 & +3.61 & +2.87 & +0.18 & +0.15 \\
\hline \multirow{5}{*}{ Dec 1970} & In & 14.7 & 0.30 & 0.23 & 0.30 & 0.09 & 0.01 & 0.02 \\
\hline & $\mathrm{T}$ & 11.7 & 0.77 & 0.27 & 0.48 & 0.16 & 0.02 & 0.04 \\
\hline & SF & 2.5 & 1.29 & 0.34 & 0.42 & 0.26 & 0.02 & 0 \\
\hline & $\mathrm{T}+\mathrm{SF}$ & 14.2 & 2.06 & 0.61 & 0.90 & 0.42 & 0.04 & 0.04 \\
\hline & Diff & -0.5 & +1.76 & +0.38 & +0.60 & +0.33 & +0.03 & +0.02 \\
\hline \multirow{5}{*}{ Jan 1971} & In & 30.9 & 0.79 & 1.11 & 0.58 & 0.22 & 0.01 & 0.01 \\
\hline & $\mathrm{T}$ & 13.8 & 1.47 & 1.16 & 0.85 & 0.37 & 0.04 & 0.01 \\
\hline & SF & 7.1 & 4.54 & 5.44 & 4.07 & 1.51 & 0.17 & 0.03 \\
\hline & $\mathrm{T}+\mathrm{SF}$ & 20.9 & 6.01 & 6.60 & 4.92 & 1.88 & 0.21 & 0.04 \\
\hline & Diff & -10.0 & +5.22 & +5.49 & +4.34 & +1.66 & +0.20 & +0.03 \\
\hline \multirow{5}{*}{$\begin{array}{c}\text { Feb + March } \\
1971\end{array}$} & In & 79.2 & 2.10 & 1.55 & 2.02 & 0.60 & 0.07 & 0.05 \\
\hline & $\mathrm{T}$ & 47.5 & 3.32 & 1.18 & 1.92 & 0.72 & 0.04 & 0.02 \\
\hline & SF & 9.3 & 2.41 & 1.51 & 0.93 & 0.71 & 0.05 & 0.01 \\
\hline & $\mathrm{T}+\mathrm{SF}$ & 56.8 & 5.73 & 2.69 & 2.85 & 1.43 & 0.09 & 0.03 \\
\hline & Diff & -22.4 & +3.63 & +1.14 & +0.83 & +0.83 & +0.02 & -0.02 \\
\hline
\end{tabular}




\section{Conitued}

\begin{tabular}{ccccccccc} 
& In & 3.2 & 0.07 & 0.06 & 0.17 & 0.04 & 0.01 & 0 \\
April 1971 & T & 1.9 & 0.08 & 0.04 & 0.11 & 0.03 & 0 & 0 \\
& SF & 0.2 & 0.02 & 0.02 & 0.01 & 0.01 & 0 & 0 \\
& T + SF & 2.1 & 0.10 & 0.06 & 0.12 & 0.04 & 0 & 0 \\
& Diff & -1.1 & +0.03 & 0 & -0.05 & 0 & -0.01 & 0 \\
Total & In & $\mathbf{5 6 4}$ & $\mathbf{1 7 . 3 0}$ & $\mathbf{1 1 . 9 1}$ & $\mathbf{1 4 . 2 1}$ & $\mathbf{4 . 4 0}$ & $\mathbf{0 . 2 6}$ & $\mathbf{1 . 3 2}$ \\
May 1970- & T & $\mathbf{3 3 2}$ & $\mathbf{2 9 . 0 8}$ & $\mathbf{1 7 . 5 1}$ & $\mathbf{1 3 . 7 0}$ & $\mathbf{6 . 1 5}$ & $\mathbf{0 . 3 8}$ & $\mathbf{1 . 2 9}$ \\
April 1971 & SF & $\mathbf{6 9}$ & $\mathbf{1 6 . 3 8}$ & $\mathbf{1 4 . 2 4}$ & $\mathbf{9 . 8 4}$ & $\mathbf{5 . 5 0}$ & $\mathbf{0 . 4 5}$ & $\mathbf{0 . 2 9}$ \\
& T SF & $\mathbf{4 0 1}$ & $\mathbf{4 5 . 4 6}$ & $\mathbf{3 1 . 7 5}$ & $\mathbf{2 3 . 5 4}$ & $\mathbf{1 1 . 6 5}$ & $\mathbf{0 . 8 3}$ & $\mathbf{1 . 5 8}$ \\
& Diff & $-\mathbf{1 6 3}$ & $+\mathbf{2 8 . 1 6}$ & $\mathbf{+ 1 9 . 8 4}$ & $\mathbf{+ 9 . 3 3}$ & $+\mathbf{+ 7 . 2 5}$ & $+\mathbf{0 . 5 7}$ & $+\mathbf{0 . 2 6}$ \\
Total & In & $\mathbf{5 9 3}$ & $\mathbf{1 8 . 3 7}$ & $\mathbf{1 0 . 9 0}$ & $\mathbf{1 3 . 1 7}$ & $\mathbf{4 . 2 6}$ & $\mathbf{0 . 3 0}$ & $\mathbf{1 . 4 2}$ \\
Nov 1969- & T & $\mathbf{3 5 5}$ & $\mathbf{2 8 . 4 6}$ & $\mathbf{1 6 . 7 6}$ & $\mathbf{1 2 . 0 0}$ & $\mathbf{5 . 6 9}$ & $\mathbf{0 . 3 3}$ & $\mathbf{1 . 4 0}$ \\
Oct 1970 & SF & $\mathbf{4 6}$ & $\mathbf{5 . 5 3}$ & $\mathbf{4 . 2 8}$ & $\mathbf{1 . 6 7}$ & $\mathbf{0 . 9 5}$ & $\mathbf{0 . 0 9}$ & $\mathbf{0 . 2 1}$ \\
& T + SF & $\mathbf{4 0 1}$ & $\mathbf{3 3 . 9 9}$ & $\mathbf{2 1 . 0 4}$ & $\mathbf{1 3 . 6 7}$ & $\mathbf{6 . 6 4}$ & $\mathbf{0 . 4 2}$ & $\mathbf{1 . 6 1}$ \\
& Diff & $-\mathbf{1 9 2}$ & $\mathbf{+ 1 5 . 6 2}$ & $\mathbf{+ 1 0 . 1 4}$ & $\mathbf{+ 0 . 5 0}$ & $+\mathbf{2 . 3 8}$ & $+\mathbf{0 . 1 2}$ & $+\mathbf{0 . 1 9}$ \\
\hline
\end{tabular}

Table 9. Sulfur and nitrogen deposition to open field and forests-a comparison of data from Jutland. Denmark and Southern Sweden showing changes over the last 50 years. Results given as $\mathrm{kg} \cdot \mathrm{ha}^{-1} \mathrm{yr}^{-1}$. Italics indicates best guess values.

\begin{tabular}{|c|c|c|c|c|c|c|c|c|c|c|c|c|c|}
\hline \multirow[t]{2}{*}{ Site } & \multirow[t]{2}{*}{ Ecosystem } & \multirow[t]{2}{*}{ Time } & \multicolumn{3}{|c|}{$\mathrm{SO}_{4}$} & \multicolumn{3}{|c|}{$\mathrm{NO}_{3}$} & \multicolumn{3}{|c|}{$\mathrm{NH}_{4}$} & \multirow{2}{*}{$\begin{array}{c}\mathbf{N} \\
\text { Total }\end{array}$} & \multirow{2}{*}{$\mathbf{R e}$} \\
\hline & & & Dry & Wet & Total & Dry & Wet & Total & Dry & Wet & Total & & \\
\hline \multirow{2}{*}{ Hestehave. DK } & \multirow{2}{*}{ Fagus sylvatica } & 1970 & ? & $15-20$ & $15-25$ & ? & ? & ? & ? & ? & $?$ & 10 & 6 \\
\hline & & 2014 & $?$ & 12 & 12 & ? & $?$ & $?$ & ? & ? & ? & 20 & 6 \\
\hline Ödum. DK & Open field & 1957-1961 & ? & 12.2 & 12.2 & $?$ & 2.2 & 2.2 & ? & 4.9 & 4.9 & 7.1 & 3 \\
\hline \multirow{2}{*}{ Skovbjerg/Buelund. DK } & Open field & 1997-2000 & ? & 7.8 & 7.8 & ? & 5.8 & 5.8 & ? & 7.1 & 7.1 & 12.9 & 4 \\
\hline & Quercus/Fagus & $1997-2000$ & $?$ & 11.5 & 11.5 & $?$ & 12.2 & 12.2 & $?$ & 8.0 & 8.0 & 20.2 & 4 \\
\hline Sepstrup Sande. DK & Open field & $1997-2000$ & 3.2 & 5.6 & 8.8 & 1.5 & 4.2 & 5.7 & 1.1 & 5.1 & 6.2 & 11.0 & 5 \\
\hline \multirow{2}{*}{ Linnebjer. SE } & Mixed Quercus & 1967 & $?$ & 34.4 & 34.4 & $?$ & $?$ & $?$ & $?$ & $?$ & $?$ & 22.3 & 1 \\
\hline & Open field & 1967 & $?$ & 11.0 & 11.0 & $?$ & $?$ & $?$ & $?$ & $?$ & $?$ & 9.4 & 1 \\
\hline \multirow{2}{*}{ Kongalund. SE } & Fagus sylvatica & 1968 & ? & 15 & 15 & $?$ & ? & ? & ? & ? & ? & 7.7 & 2 \\
\hline & Open field & 1968 & ? & 9 & 9 & ? & ? & $?$ & ? & ? & ? & 9 & 2 \\
\hline
\end{tabular}

References: 1. Andersson, 2014. 2. Nihlgård, 1972. 3. Jensen, 1962. 4. Pedersen et al., 2001. 5 Oral comm. T Ellerman 6. This paper. ? Not measured.

Table 10. Distribution of elements in soil organic matter (SOM) and in fractions exchangeable in ammonium acetate (AmAc) and EDTA in the Danish IBP-PT beech forest in Hestehave, Kalö, Jutland, Denmark.

\begin{tabular}{|c|c|c|c|c|c|c|c|c|c|c|c|c|c|}
\hline \multirow{2}{*}{ Fraction } & Organic matter & $\mathrm{C}$ & $\mathrm{N}$ & $\mathrm{C} / \mathrm{N}$ & $\mathrm{Na}$ & $\mathrm{K}$ & $\mathrm{Ca}$ & $\mathrm{Mg}$ & $\mathrm{Mn}$ & $\mathrm{Fe}$ & $\mathrm{Zn}$ & $\mathrm{Cu}$ & $\mathrm{P}$ \\
\hline & $\mathrm{t} \cdot \mathrm{ha}^{-1}$ & \multicolumn{2}{|c|}{$\mathrm{t} \cdot \mathrm{ha}^{-1}$} & ratio & \multicolumn{9}{|c|}{$\mathrm{kg} \cdot \mathrm{ha}^{-1}$} \\
\hline \multirow[t]{2}{*}{ Soil organic matter 0 - $80 \mathrm{~cm}$} & 360 a) & & & & & & & & & & & & \multirow{4}{*}{$\begin{array}{c}256 \\
-\end{array}$} \\
\hline & 141 b) & 70.7 & 7.52 & 9.7 & - & - & - & - & - & - & - & - & \\
\hline AmAc-exchangeable & - & - & Negl. & - & 660 & 193 & 2308 & 22 & 4176 & 1621 & - & - & \\
\hline EDTA-exchangeable & - & - & - & - & - & - & - & - & - & - & 47.8 & 12.1 & \\
\hline
\end{tabular}

a) Unreduced loss on ignition; b) $\mathrm{C} \times 2$.

The observed increase in diameter, height plant biomass and production of the investigated beech forest in Hestehave was interpreted as a result of a changing environment over time. In a Danish study (Skovgaard \& Henriksen, 1996) reported a significantly increased productivity expressed as increased tree height growth. App. a 3.6 m height increase was found during the period 1920s - 1990. In an investigation led by European Forest Institute (EFI, 1996; 1999) focusing on the importance of a changing environment it was found that an increasing growth was found in large parts of Europe. The reasons behind this could be different factors. Most likely the increased $\mathrm{CO}_{2}$ level, increased nitrogen deposition and temperature were emphasized. The increased temperature implies also a longer growth period.

In a recent study of a number of European long-term forest experiments have been analysed (Pretzsch et al., 2014). It is concluded that the dynamics of forest growth has accelerated in Europe since 1870. European beech is one of the tree species treated and 22 experiments had been considered. 36 Norway spruce experiments were also analysed. It was found that there is a faster tree growth (+32 to $77 \%)$, increased stand volume growth (+10 
Table 11. Distribution of elements in some important aboveground functional fractions and turnover characteristics in the Danish IBP-PT beech forest in Hestehave, Kalö, Jutland, Denmark.

\begin{tabular}{|c|c|c|c|c|c|c|c|c|c|c|c|c|}
\hline \multirow{2}{*}{ Symbol } & \multirow{2}{*}{ Fraction } & Weight & $\mathrm{C}$ & $\mathrm{N}$ & $\mathrm{C} / \mathrm{N}$ & $\mathrm{Na}$ & K & $\mathrm{Ca}$ & $\mathrm{Mg}$ & $\mathrm{Fe}$ & $\mathrm{Mn}$ & $\mathrm{P}$ \\
\hline & & $\mathrm{t} \cdot \mathrm{ha}^{-1}$ & $\mathrm{t} \cdot \mathrm{ha}{ }^{-1}$ & $\mathrm{t} \cdot \mathrm{ha}^{-1}$ & ratio & \multicolumn{7}{|c|}{$\mathrm{kg} \cdot \mathrm{ha}^{-1}$} \\
\hline $\mathrm{P}$ & Yearly production & 13.7 & 5.95 & 0.128 & 47 & 4.45 & 32.60 & 100.59 & 11.06 & 0.59 & 1.64 & 11.61 \\
\hline$\Delta \mathrm{B}$ & Yearly biomass increase & 10.8 & 4.77 & 0.076 & 63 & 1.66 & 15.94 & 39.50 & 5.27 & 0.34 & 0.69 & 4.97 \\
\hline $\mathrm{L}$ & Yearly litter fall $(x)$ & 3.2 & 1.61 & 0.033 & 49 & 2.40 & 8.50 & 33.10 & 5.18 & $?$ & $?$ & 1.70 \\
\hline $\mathrm{C}$ & Canopy leached fraction & - & - & $?$ & - & 15.62 & 10.14 & 0.50 & 2.38 & ? & 0.12 & 0.19 \\
\hline SL & Surface litter & 4.3 & 1.42 & 0.048 & 30 & 1.26 & 9.99 & 50.10 & 8.16 & ? & - & 4.78 \\
\hline $\mathrm{S}$ & Soil organic matter & 141 & 70.7 & 7.52 & 10 & - & - & - & - & & - & - \\
\hline \multirow[t]{4}{*}{ Exch } & Exch. in soil & - & - & Insig. & - & 660 & 193 & 2308 & 22 & 1621 & 4176 & 256 \\
\hline & $\mathrm{P}-\Delta \mathrm{B}$ & 2.9 & 1.18 & 0.052 & - & 2.79 & 16.62 & 41.09 & 5.79 & 0.25 & 0.95 & 6.64 \\
\hline & $\mathrm{L}+\mathrm{C}$ & - & - & $?$ & - & 18.02 & 18.64 & 33.60 & 7.56 & $?$ & $?$ & 1.89 \\
\hline & $\mathrm{L} / \mathrm{L}+\mathrm{SL}$ & 0.43 & 0.53 & 0.64 & - & 0.66 & 0.46 & 0.40 & 0.39 & $?$ & ? & 0.26 \\
\hline
\end{tabular}

(x) Not branches $>0.50 \mathrm{~cm}$; ? = not measured.

to $20 \%$ ), increased tree biomass accumulation (+6 to $7 \%$ ); tree numbers are lower and self-thinning remains constant.

\section{Conclusion}

In this paper the original results from 1970 on tree biomass, production and mineral cycling are reported. Of particular interest has been to elucidate if the Hestehave forest today is a source or sink for carbon. It was concluded that it is still a sink. This was revealed trough a new analyse in 2014 of tree diameter and height. Unexpected high values for increased diameter, height, tree biomass and production were found. In comparison with other data, the results seem most likely to be correct although a reservation has been given on methodological matters. A number of properties, which are changing in the forest dynamics today can be verified from the reported findings in the repeated Hestehave investigation. Financial resources were lacking for a more detailed analysis. New knowledge is needed on today's forests for their management. The value of long-term experiments needs to be stressed.

\section{Acknowledgements}

These investigations were mainly carried out upon invitation of the Hestehave project. The late Professor $\mathrm{H}$ M Thamdrup is acknowledged as the previous staff of the Hestehave project. Special thanks go to Henning Petersen, Mols for facilitating contacts and making arrangements for earlier investigations and those in 2014. M Astrup, A Büow-Olsen and B Overgaard Nielsen are also gratefully acknowledged for sharing information. The field work in 1970 was done by a group of Danish students supported by Swedes, especially Håkan Staaf. Computer and statistical advice and help were received from C Sjögren and B Zöger. The final field work in the laboratory was done at the former Department of Plant Ecology, University of Lund headed by Prof Nils Malmer. Financial support was received from the Swedish Natural Science Research Council. U. Johansson has critically read and commented the manuscript constructively. He has also provided his own experience and literature information on production of beech in a European perspective. P. Madsen has also read the manuscript and provided information on Danish conditions.

In the field work 2014 I was assisted by E Mogensen-Christensen, H Petersen and K Dalsgaard. Special thanks go to Prof em Göran Ågren for assistance in making the final calculations of tree biomass and production. Constant encouragement and technical support has been given by my wife Pirjo.

\section{References}

Ågren, G. I., \& Andersson, F. O. (2012). Terrestrial Ecosystem Science-Principles and Applications (p. 230). Cambridge: Cambridge University Press.

Andersson, F. O. (2014). Plant Biomass, Primary Production and Mineral Cycling of a Mixed Oak Forest on Linnebjer, Sweden. Open Journal of Forestry, 4, 570-580. http://dx.doi.org/10.4236/ojf.2014.45061

Andersson, F. (1970a). An Ecosystem Approach to Vegetation, Environment and Organic Matter of a Mixed Woodland and Meadow Area. Thesis, Lund: Lund University. 
Andersson, F. (1970b). Ecological Studies in a Scanian Woodland and Meadow Area, Southern Sweden. I. Vegetational and Environmental Structure. Opera Botanica, 27, 190.

Andersson, F. (1970c). Ecological Studies in a Scanian Woodland and Meadow Area, Southern Sweden. II Plant Biomass, Primary Production and Turnover of Organic Matter. Botaniska Notiser, 123, 8-51.

Andersson, F. (1973). Note See Thamdrup, H.M.

Astrup, M., \& Bülow-Olsen, A. (1979). Nutrient Cycling in Two Danish Beech forests Growing on Different Soil Types. Holsarctic Ecology, 2, 125-129.

Bahn, M., Reichstein, M., Davidson, E. A., Grümzwig, J., Jung, N., Carbone, M. S., Epron, D., Misson, L., Nouvellon, Y., Roupsard, O., Savage, K., Trumbore, S. E., Gimenci, C., Curiel Yuste, J., Tang, J., Vargas, R., \& Janssens, I. A. (2010). Soil Respiration at Mean Annual Temperature Predicts Annual Total over Vegetation Types and Biomes. Biogeosciences, 7, 2147-2157. http://dx.doi.org/10.5194/bg-7-2147-2010

Boysen Jensen, P. (1932). Die Stoffproduktion der Pflanzen (108 p). Jena: Verlag von Gustav Fischer.

Bülow-Olsen, A. (1977). Biomass Studies of Ground Vegetation in Beech Forests (44 p). Thesis of Licentiate, Copenhagen: Department of Botany, Royal Veterinary and Agricultural University. (In Danish)

Dalsgaard, K. (1983). Examples of Danish Profiles of Soil Types (79 p). Geokomp. Nr. 22. Aarhus: Geological Institute, University of Aarhus.

EFI (1996). Growth Trends in European Forests. European Forest Research Institute Report, 5, 90-97.

EFI (1999). Causes and Consequences of Accelerating Tree Growth in Europe. EFI Proceedings, 27, 265 p.

Ellenberg, H., Mayer, R., \& Schauermann, J. (1986). Ökosystemforschung. Ergebnisse des Solling-Projekts (507 p). Stuttgart: Ulmer Verlag.

Hughes, M. K. (1975). Ground Vegetation, Net Production in a Danish Beech Wood. Oecologia, 18, 251-258. http://dx.doi.org/10.1007/BF00345427

Jensen, J. (1962). Investigations of the Content of Plant Nutrients in Precipitation. Tidskrift for Planteavel, 65, 894-906. (In Danish)

Jörgensen, V. (1978). The Content of Plant Nutrients in Precipitation 1970-74. Meddelande fra Statens Planteavelförsög., No. 1168. (In Danish)

Möller, C. M., Mûller, D., \& Nielsen, J. (1954). Ein Diagram det Stoffproduktion im Buchenwald. Berichte der Schweizerischen Botanischen Gesellschaft, 64, 487-494.

Nielsen, B. O. (1977). Seasonal and Annual Variation in Litter Fall in a Beech Stand 1967-75. Fortslige Forsogsvesen $i$ Danmark, 35, 15-38.

Nihlgård, B. (1970). Precipitation, Its Chemical Composition and Effect on Soil Water in a Beech and a Spruce Forest in South Sweden. Oikos, 21, 208-217. http://dx.doi.org/10.2307/3543676

Nihlgård, B. (1972). Plant Biomass, Primary Production and Distribution of Chemical Elements in a Beech and a Planted Spruce Forest in South Sweden. Oikos, 23, 68-91. http://dx.doi.org/10.2307/3543928

Nihlgård, B., \& Lindgren, L. (1977). Plant Biomass, Primary Production and Bioelements of Three Mature Beech Forests in South Sweden. Oikos, 28, 95-104. http://dx.doi.org/10.2307/3543328

Pedersen, A. R. (2011). Variation of pH over Time in the Forest of Hestehave (23 p). Bachelor Report, Aarhus: Geological Institute, University of Aarhus. (In Danish)

Pedersen, L. B., Ingerlev, M., Buttenschön, R. M., Friiss, E., \& Nielsen, B. O. (2001). Effects of Grazing of Husbandry animals on Mineral Cycling in Extensively Manages Natural Areas. Park and Landscape Series, Skov \& Landskab, 34, 49-66.

Pretzsch, H., Biber, P., Schütze, G., Uhl, E., \& Rötzer, T. (2014). Forest Stand Growth Dynamics in Central Europe Have Accelerated since 1870. Nature Communications, 5, 1-10. http://dx.doi.org/10.1038/ncomms5967

Reichle, D. E. (1981). Dynamic Properties of Forest Ecosystems. International Biological Programme 23. Cambridge: Cambridge University Press.

Skovgaard, J. P., \& Henriksen, H. A. (1996). Increasing Site Productivity during Consecutive Generations of Naturally Regenerated and Planted Beech (Fagus sylvativca L.) in Denmark. European Forest Research Institute Report, 5, 90-97.

Tamm, C. O., \& Hallbäcken, L. (1988). Changes in Soil Acidity in Two Forest Areas with Different Acid Deposition: 1920s to 1980 s. Ambio, 17, 56-61.

Thamdrup, H. M. (1973). The Danish IBP Woodland Project. In: Modelling Forest Ecosystems. Report of IBP Woodland Workshop, IBP/PT Section, 14-26 August 1972. Oak Ridge Report EDFBIBP, 747, 231-250. 


\section{Appendix 1}

\section{The Hestehave Project (Publication List Latest, Update: July 2014)}

\section{Published in Scientific Journals or Books}

Astrup, M., \& Bülow-Olsen, A. (1979). Nutrient Cycling in Two Danish Beech forests Growing on Different Soil Types. Holsarctic Ecology, 2, 125-129.

Dalsgaard, K., Baastrup, E., \& Bunting, B. T. (1981). The Influence of Topography and the Development of Alfisols on Calcareous Clayey Till in Denmark. Catena, 8, 111-136. http://dx.doi.org/10.1016/S0341-8162(81)80008-2

De Angelis, D. L., Gardner, R. H., \& Shugart, H. H. (1981). Productivity of Forest Ecosystems Studied during the IBP: The Woodland Data Set. In D. E. Reichle (Ed.), Dynamic Properties of Forest Ecosystems. International Biological Programme 23 (pp. 567-672). Cambridge: Cambridge University Press.

Hallas, T. E., \& Yeates, G. W. (1972). Tardigrada of the Soil and Litter of a Danish Beech Forest. Pedobiologia, 12, 287304.

Holm, E., \& Jensen, V. (1972). Aerobic Chemoorganotrophic Bacteria of a Danish Beech Forest. Microbiology of a Danish Beech Forest I. Oikos, 23, 248-260. http://dx.doi.org/10.2307/3543413

Holm, E., \& Jensen, V. (1980). Microfungi of a Danish Beech Forest. Microbiology of a Danish Beech Forest. II. Holarctic Ecology, 3, 19-25.

Hughes, M. K. (1975). Ground Vegetation, Net Production in a Danish Beech Wood. Oecologia, 18, 251-258. http://dx.doi.org/10.1007/BF00345427

Jensen, T. S. (1975a). Trappability of Various Functional Groups of the Forest Rodents Clethrionomys glareolus and Apodemus flavicollis, and Its Application in Density Estimations. Oikos, 26, 196-204. http://dx.doi.org/10.2307/3543709

Jensen, T. S. (1975b). Population Estimations and Population Dynamics of Two Danish Forest Rodent Species. Videnskabelige Meddelelser Dansk Naturhistorisk Forening, 138, 65-86.

Jensen, T. S. (1981). Energy Flow through Danish Forest Rodent Populations. Natura Jutlandica, 19, 73-80.

Jensen, T. S. (1982). Seed Production and Outbreaks of Non-Cyclic Rodent Populations in Deciduous Forests. Oecologia, 54, 184-192. http://dx.doi.org/10.1007/BF00378391

Jensen, T. S. (1984). Habitat Distribution, Home Range and Movements of Rodents in Mature Forest and Reforestation. Acta Zoologica Fennica, 171, 305-307.

Jensen, V. (1971). The Bacterial Flora of Beech Leaves. In T. F. Preece, \& C. H. Dickinson (Eds.), Ecology of Leaf Surface Micro-Organisms (pp. 463-469). Waltham: Academic Press.

Jensen, V. (1974). Decomposition of Angiosperm Tree Leaf Litter. In C. H. Dickinson, \& G. J. F. Pugh (Eds.), Biology of Plant Litter Decomposition Vol. 1 (pp. 69-104). Waltham: Academic Press.

http://dx.doi.org/10.1016/B978-0-12-215001-2.50009-X

Jensen, T. F. (1975). A Tentative Energy Budget for a Summer Population of Arion ater L. (Gastropoda: Pulmonata). Natura Jutlandica, 18, 10-20.

Jørum, P. (1976a). A Study on the Composition and Seasonal Activity of the Ground Beetle Fauna of a Danish Beech Forest. Entomologiske Meddelelser, 44, 81-99. (In Danish with English summary)

Jørum, P. (1976b). Life Cycle and Population Density of Nebria brevicollis F. (Coleoptera, Carabidae) in a Danish Beech Forest. Videnskabelige Meddelelser Dansk Naturhistorisk Forening, 139, 245-261.

Jørum, P. (1980). Life Cycles and Annual Activity Patterns of Pterostichus melanarius (Illig.) and P. niger (Schall.) (Coleoptera: Carabidae) in a Danish Beech Wood. Entomologiske Meddelelser, 48, 19-25.

Kjøller, A., \& Struwe, S. (1982). Microfungi in Ecosystems: Fungal Occurrence and Activity in Litter and Soil. In H. Petersen (Ed.), Quantitative Ecology of Microfungi and Animals in Soil and Litter. Oikos, 39, 389-422.

Lindgreen, H. P., \& Jensen, V. (1973). Microbiological Examinations of a Forest Soil Profile (pp. 147-159). Yearbook, Copenhagen: The Royal Veterinary and Agricultural University.

Luxton, M. (1972). Studies on the Oribatid Mites of a Danish Beech Wood Soil I. Nutritional Biology. Pedobiologia, 12, 434-463.

Luxton, M. (1975). Studies on the Oribatid Mites of Danish Beech Wood Soil. II. Biomass, Calorimetry and Respirometry. Pedobiologia, 15, 161-200.

Luxton, M. (1981a). Studies on the Oribatid Mites of a Danish Beech Wood Soil. III. Introduction to the Field Populations. Pedobiologia, 21, 301-311.

Luxton, M. (1981b). Studies on the Oribatid Mites of a Danish Beech Woods Soil. IV. Developmental Biology. Pedobiolo- 
gia, 21, 312-340.

Luxton, M. (1981c). Studies on the Oribatid Mites of a Danish Beech Wood Soil. V. Vertical Distribution. Pedobiologia, 21, 365-386.

Luxton, M. (1981d). Studies on the Oribatid Mites of a Danish Beech Wood Soil. VI. Seasonal Population Changes. Pedobiologia, 21, 387-409.

Luxton, M. (1981e). Studies on the Oribatid Mites of a Danish Beech Wood Soil. VII. Energy Budgets. Pedobiologia, 22, 77-111.

Luxton, M. (1981f). Studies on the Astigmatic Mites of a Danish Beech Wood Soil. Pedobiologia, 22, 29-38.

Luxton, M. (1981g). Studies on the Prostigmatic Mites of a Danish Beech Wood Soil. Pedobiologia, 22, 277-303.

Luxton, M. (1982). The Biology of Mites from Beech Woodland Soil. Pedobiologia, 23, 1-8.

Luxton, M. (1984). Patterns of Food Intake by Some Macrophytophagous Mites of Woodland Soil. Acaroecology, 6, 534543.

Luxton, M. (1995). Patterns of Food Intake by Some Astigmatic Mites of Beech Woodland Soil (Acari: Astigmata). Pedobiologia, 39, 238-242.

Luxton, M. (1991). Seasonal and Spatial Variation in Food Intake by the Oribatid Mites of Beech Woodland Soil. In R. Schuster, \& P. W. Murphy (Eds.), The Acari: Reproduction, Development and Life-History Strategies (pp. 459-471). London: Chapman \& Hall.

Nielsen, B. O., \& Nielsen, L. B. (2007). Soil Diptera of a Beech Stand and an Arable Field: A Comparison of Dipteran Emergence in Neighbouring Sites. Pedobiologia, 51, 33-43. http://dx.doi.org/10.1016/j.pedobi.2006.12.002

Nielsen, B. O., \& Nielsen, L. B. (2009). Mosquitoes (Diptera: Nematocera) Hatched from the Forest Floor of a Beech Stand (Myg (Diptera: Nematocera) klækket fra skovbunden i en bøgebevoksning). Entomologiske Meddelelser, 77, 117-135. (In Danish with English summary)

Nielsen, B. O., \& Nielsen, S. A. (1986). Height of Flight of Some Insects in a Beech Stand. Flora og Fauna, Aarhus, 92, 51-52. (In Danish with English summary)

Nielsen, B. O., \& Ejlersen, A. (1977). The Distribution Pattern of Herbivory in a Beech Canopy. Ecological Entomology, 2, 293-299. http://dx.doi.org/10.1111/j.1365-2311.1977.tb00894.X

Nielsen, B. O. (1974a). A Record of Insect Activity on Beech Stems (Fagus sylvatica L.) by Means of Arboreal Photoeclectors. Entomologiske Meddelelser, 42, 1-18. (In Danish with English summary)

Nielsen, B. O. (1974b). The Insect Fauna Recorded by Means of Trapbanding on Beech (Fagus sylvatica L.). Flora og Fauna, 80, 53-61. (In Danish with English summary)

Nielsen, B. O. (1974c). The Phenology of Beech Canopy Insects in Denmark. Videnskabelige Meddelelser Dansk Naturhistorisk Forening, 137, 95-124.

Nielsen, B. O. (1974d). Studies on the Weevils (Curculionidae) of a Danish Beech Forest. Entomologiske Meddelelser, 42, 169-188. (In Danish, with English summary)

Nielsen, B. O. (1975a). Sampling of Arboreal Insects from Beech by Beating Stems with Clubs. Entomologiske Meddelelser, 43, 37-61. (In Danish with English summary)

Nielsen, B. O. (1975b). The Insect Fauna in the Herb Layer of a Danish Beech Stand. Entomologiske Meddelelser, 43, 145-171. (In Danish, with English summary)

Nielsen, B. O. (1975c). The Species Composition and Community Structure of the Beech Canopy Fauna in Denmark. Videnskabelige Meddelelser Dansk Naturhistorisk Forening, 138, 137-170.

Nielsen, B. O. (1977a). Seasonal and Annual Variation in Litter Fall in a Beech Stand 1967-75. Fortslige Forsogsvesen i Danmark, 35, 15-38.

Nielsen, B. O. (1977b). Beech Seeds as an Ecosystem Component. Oikos, 29, 268-274. http://dx.doi.org/10.2307/3543613

Nielsen, B. O. (1978a). Food Resource Partition in the Beech Leaf-Feeding Guild. Ecological Entomology, 3, $193-201$. http://dx.doi.org/10.1111/j.1365-2311.1978.tb00919.x

Nielsen, B. O. (1978b). Above Ground Food Resources and Herbivory in a Beech Forest Ecosystem. Oikos, 31, $273-279$. http://dx.doi.org/10.2307/3543650

Nielsen, B. O. (1978c). Aspects of the Population Ecology and Energetic of Some Beech Leaf-Feeding Insects. Natura Jutlandica, 20, 259-272.

Nielsen, B. O. (1986). The Emergence and Aerial Distribution of Soil Diptera in Beech Woodland. 1st International Congress of Dipterology, Budapest, Abstract, 181.

Nielsen, B. O. (1987a). Vertical Distribution of Insect Populations in the Free Air Space of Beech Woodland. Entomologiske 
Meddelelser, 54, 169-178.

Nielsen, B. O. (1987b). Mosquitoes (Culicidae) Recorded in Light Traps in a Beech Stand. Flora og Fauna, 93, 37-38. (In Danish with English summary)

Nielsen, B. O. (1987c). The Food of the Woodland Earwig (Chelidurella acanthopygia Géné) (Dermaptera, Forficulidae). Entomologiske meddelelser, 54, 125-128. (In Danish with English summary)

Nielsen, E. S. (1977). Studies on Lacewings (Neuroptera s.str.) in a Danish Beech Stand. Entomologiske meddelelser, 45, 45-64. (In Danish with English summary)

Petersen, H. (1971a). Parthenogenesis in Two Common Species of Collembola: Tullbergia krausbaueri (Börner) and Isotoma notabilis Schäffer. Review of Ecological and Biological Soil Studies, 8, 133-138.

Petersen, H. (1971b). The Nutritional Biology of Collembola and Its Ecological Significance. A Review of Recent Literature with a Few Original Observations (Collembolernes ernæringsbiologi og dennes økologiske betydning). Entomologiske Meddelelser, 39, 97-118. (In Danish with English summary)

Petersen, H. (1971c). Methods for Estimation of Growth of Collembola in Cultures and in the Field, Exemplified by Preliminary Results for Onychiurus furcifer (Börner). Proceedings of IV. Colloquium Pedobiologiae, Dijon, 14/19-IX-1970. Annales de Zoologie Ecologie Animale (Hors-Série), 235-254.

Petersen, H. (1975). Estimation of Dry Weight, Fresh Weight and Calorific Content of Various Collembola Species. Pedobiologia, 15, 222-243.

Petersen, H. (1978a). Sex-Ratios and the Extent of Parthenogenetic Reproduction in Some Collembolan Populations. In: R. Dallai (Ed.), 1st International Seminary on Apterygota, Siena, 13-15 September 1978, Accademia delle Scienze di Siena detta de'Fisiocritici, 19-35.

Petersen, H. (1978b). Some Properties of Two High-Gradient Extractors for Soil Microarthropods, and an Attempt to Evaluate Their Extraction Efficiency. Natura Jutlandica, 20, 95-122.

Petersen, H. (1980). Population Dynamic and Metabolic Characterization of Collembola Species in a Beech Forest Ecosystem. In D. L. Dindal (Ed.), Soil Biology as Related to Land Use Practices. Proc.VII Int. Soil Zool. Colloq. of the I.S.S.S., Syracuse, 29 July-3 August 1979, EPA560/13-80-038, Washington D.C., 806-833.

Petersen, H. (1981a). Open Gradient Diver Respirometry Modified for Terrestrial Arthropods. Oikos, 37, $265-272$. http://dx.doi.org/10.2307/3544117

Petersen, H. (1981b). The Respiratory Metabolism of Collembola Species from a Danish Beech Wood. Oikos, 37, $273-286$. http://dx.doi.org/10.2307/3544118

Petersen, H. (1995). Energy Flow and Trophic Relations in Soil Communities: State of Knowledge Two Decades after the International Biological Programme. In C. A. Edwards, T. Abe, \& B. R. Striganova (Eds.), Structure and Functioning of Soil Communities (pp. 111-130). Kyoto: Kyoto University Press.

Petersen, H. (2002). General Aspects of Collembolan Ecology at the Turn of the Millenium. Pedobiologia, 46, $246-260$.

Petersen, H., \& Luxton, M., (1982). A Comparative Analysis of Soil Fauna Populations and Their Role in Decomposition Processes. In H. Petersen (Ed.), Quantitative Ecology of Microfungi and Animals in Soil and Litter. Oikos, 39, 287-388.

Petersen, H. (1994). A Review of Collembolan Ecology in Ecosystem Context. Acta Zoologica Fennica, 195, 111-118.

Petersen, H., O’Neill, R. V., \& Gardner, R. H. (1985). Use of an Ecosystem Model for Testing Ecosystem Responses to Inaccuracies of Root and Microflora Productivity Estimates. In A. F. Fitter (Ed.), Ecological Interactions in Soil (pp. 233-242). Special Publication Number 4 of the British Ecological Society, Blackwell Scientific Publications.

Rasmussen, S., Nielsen, M. K., \& Hansen, J. P. N. (1982). The Climate of a Danish Beechwood, Hestehaven, Eastern Jutland. Holarctic Ecology, 5, 412-419.

Stout, J. D. (1972). Response of Some Soil Bacteria and Yeasts to Glucose. Soil Biology and Biochemistry, 4, 533-536. http://dx.doi.org/10.1016/0038-0717(72)90069-7

Thamdrup, H. M. (1973). The Danish IBP Woodland Project. In L. Kern (Ed.), Modeling Forest Ecosystems (pp. 231-250). Report of International Woodland Workshop, International Biological Program/PT Section, 14-26 August 1972. Oak Ridge National Laboratory. EDFB-IBP-73-7. UC-48-Biology and Medicine.

Toft, S. (1976). Life Histories of Spiders in a Danish Beech Wood. Natura Jutlandica, 19, 5-40.

Toft, S. (1978). Phenology of Some Danish Beech-Wood Spiders. Natura Jutlandica, 20, 285-301.

Yeates, G. W. (1971). Feeding Types and Feeding Groups in Plant and Soil Nematodes. Pedobiologia, 11, 173-179.

Yeates, G. W. (1972a). Nematoda of a Danish Beech Forest. I. Methods and General Analysis. Oikos, 23, 178-189. http://dx.doi.org/10.2307/3543403

Yeates, G. W. (1972b). Population Studies on Ditylenchus dipsaci (Nematoda: Tylenchida) in a Danish Beech Forest. Nematologica, 18, 125-130. http://dx.doi.org/10.1163/187529272X00304 
Yeates, G. W. (1972c). Constancy of Specific Soil Nematode Dimensions with Depth and Time. Nematologica, 18, 418. http://dx.doi.org/10.1163/187529272X00700

Yeates, G. W. (1973). Nematoda of a Danish Beech Forest. II. Production Estimates. Oikos, 24, 179-185. http://dx.doi.org/10.2307/3543873

Yeates, G. W. (1977). Nematoda of a Danish Beech Forest: A Correction. Oikos, 28, 309. http://dx.doi.org/10.2307/3543987

Published in Popular Science Journals or Books

Callesen, I., Vejre, H., Dalsgaard, L., Petersen, H., \& Møller, P. F. (2010). The Inherent Natural Framework of the Forests (Skovenes Naturgivne Rammer). Chapter 2. In P. F. Møller (Ed.), The Nature in Denmark: The Forests (Naturen i Danmark: Skovene) (pp. 29-53). København: Gyldendal. (In Danish) http://www.denstoredanske.dk/Naturen_i_Danmark/NaDanish

Gjelstrup, P., \& Petersen, H. (1987). Mites and Springtails in Soil (Jordbundens Mider og Springhaler). Natur og Museum, 26, 31 p. (In Danish)

Heilmann-Clausen, J., Nielsen, B. O., Petersen, H., \& Mather-Christensen, O. (2010). Decomposition (Nedbrydning). Chapter 10. In P. F. Møller (Ed.), The Nature in Denmark: The Forests (Naturen i Danmark: Skovene) (pp. 247-269). København: Gyldendal. (In Danish)

Nielsen, B. O., Petersen, H. Gjelstrup, P., Mather-Christensen, O., Sangild, S., Heilmann-Clausen, J., \& Fog, K. (2010). The Small Organisms in the Forest and Their Mutual Interactions (Skovenessmåorganismerogderessamspil). Chapter 7. In P. F. Møller (Ed.), The Nature in Denmark: The Forests (Naturen i Danmark: Skovene) (pp. 163-193). København: Gyldendal. (In Danish)

Petersen, H. (2002). General Aspects of Collembolan Ecology at the Turn of the Millenium. Pedobiologia, 46, $246-260$.

Petersen, H., \& Luxton, M. (1982). A Comparative Analysis of Soil Fauna Populations and Their Role in Decomposition Processes. In H. Petersen (Ed.), Quantitative Ecology of Microfungi and Animals in Soil and Litter. Oikos, 39, 287-388. 